\title{
Ethics and aesthetics of Holocaust memory
}

\author{
EDITORIAL
}

W ith one exception, all contributions in this special issue of Scandinavian Jewish Studies are revised lectures given at the Centre for the Study of Jewish Thought in Modern Culture (CJMC), University of Copenhagen, between 2014 and 2016.

CJMC was launched in 2014. It provides an open forum for exchange and exploration of Jewish thought and experience and their impact on modern and postmodern philosophy, theology, psychology, history, sociology, literature, art and culture in general. CJMC's multidisciplinary approach is propelled by scholarly interests not only in classical, but also in forgotten or understudied Jewish sources and their capacity to enrich contemporary culture. With this background, we seek to initiate a dialogue between foreign and familiar voices from the past and present, and to link internal and external perspectives on Jewish thought.

Some of the CJMC lectures collected in this special issue of Scandinavian Jewish Studies were presented in the context of conferences, workshops and research seminars at the centre:

- 'Aesthetics of memory'(2 I.I0.2014)

- 'Representations of the Holocaust in literature, art and film' (I4.I I.20I4)

- 'Post-Holocaust theology, philosophy and literature' $(5 \cdot 5 \cdot 2015)$

- '(Hi)Stories of Holocaust memory' (I8.-19.5.2015)

- 'Judaism, writing, and oral history after I $945^{\prime}(8.4 .20$ I 6$)$
A recurrent question that connects these events is this: how can we preserve and transfigure the memory of catastrophe when that which called it forth recedes further and further into the past, while, at the same time, we will never be able to leave it behind? The Shoah and its aftermath belong not just to the past but also impose themselves repeatedly on our present, interfering in disturbing ways.

Today, more than seventy years after the end of the Second World War and the liberation of the concentration camps, we still carry the burden of history and its onerous legacy. In one way or another, most countries, societies and individuals have participated in this atrocious past and struggle with its aftermath.

Through inter-generational transmission, Holocaust memory turns from first-hand to second-hand recollection. The connection to the past is then mediated, for example, by written testimonies and stories, photography and film, monuments and architecture, behaviour and gesture. Once the last eyewitnesses have passed away, knowledge about past events will no longer be based on personal experience, but can only be recalled by means of imaginative investment. How can we then avoid oblivion, re-present the past, and protect and appropriate the hard-earned insights of others? Not only the second generation, but also the third, fourth, and coming generations, too, carry responsibility for how this historical heritage is received and handed down. 
In what ways can processes of commemoration be stimulated, indifference turned into attention and traumatic memories worked through? What strategies of expression, re-presentation and communication have proved particularly successful in evoking critical reflection? By what means do they speak to the senses and the intellect, touch people emotionally and open up new space for the imagination?

These questions are addressed in this special issue of Scandinavian Jewish Studies on 'Ethics and Aesthetics of Holocaust Memory', which combines investigations into contemporary art and literature.

In the first two contributions, art history and theory, memory and performance studies coalesce. They explore possibilities and limitations of memorial objects and landscapes and address the question at the core of this composite field, of how the interplay between words and images, the use of syn[a] esthetic techniques and the creation of time-interfaces are to be understood in contemporary art. For instance, what happens when dialogical aesthetics and performative practices of placing viewers in interlocutory situations come into focus?

The remaining three contributions examine different ways in which literature reflects and responds to the Shoah. Questions concerning the significance of trauma discourse in current research in Holocaust narratives are probed. The ways in which children of the victims and children of perpetrators work through their own experiences come to the fore with special emphasis on cases, fraught with frustration and complication, where authentic connection to the event itself no longer exists. The wealth of factual and fictional representations of the Holocaust - which often play an ambiguous, if not dubious, role in identity politics - prompts reflection on our own historical position in relation to the past, on the problematics of rendering past reality with accuracy, and on the reliability of remaining traces.
One of the crucial questions that concerns all forms of Holocaust commemoration is how freedom and dignity can be preserved or regained despite the shadows of a dark and difficult past. The present issue of Scandinavian Jerwish Studies seeks to stimulate discussions on these matters - not least through a thought-provoking supplement: the essay 'Memory, shame and dignity' by the Swedish writer and journalist Göran Rosenberg.

\section{CLAUDIA WELZ and INGE BIRGITTE SIEGUMFELDT}

Guest editors

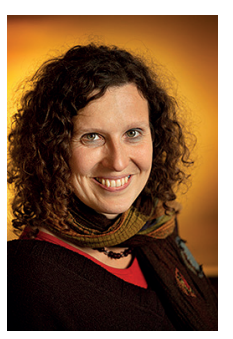

Claudia Welz is Professor of Systematic Theology with special responsibilities in Ethics and Philosophy of Religion at the University of Copenhagen and Founding Director of CJMC: Centre for the Study of Jewish Thought in Modern Culture. She is the author of the books Love's Transcendence and the Problem of Theodicy

(Mohr Siebeck, 2008), Vertrauen und Versuchung (Mohr Siebeck, 2010), Humanity in God's Image: An Interdisciplinary Exploration (Oxford University Press, 2016), and has co-authored and edited the anthologies Despite Oneself: Subjectivity and its Secret in Kierkegaard and Levinas (2008), Trust, Sociality, Selfhood (2010), and Ethics of In-Visibility: Imago Dei, Memory, and Human Dignity in Jewish and Christian Thought (2015). Her research interests embrace also German-Jewish literature, trauma and memory studies, modern and post-Holocaust theology, phenomenology, theories of subjectivity, philosophy of language and of emotion as well as psycho(patho)logy.

\section{Inge Birgitte Siegumfeldt is} Associate Professor in Contemporary Literatures in English, Department of English, German and Romance Studies, University of Copenhagen. She has previously published on Jewish aspects of Yale School Criticism, Poststructuralist and Deconstructive theory and is

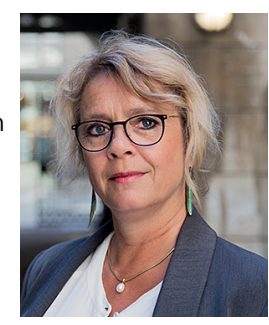
currently working on a critical study of parallelism in twenty-first century American literature. Her latest publication was co-authored with the American writer, Paul Auster, ... en verden i ord. Paul Auster $i$ samtale med Inge Birgitte Siegumfeldt, 2016 (Danish trans. of $A$ Life in Words: Paul Auster in Conversation with I. B. Siegumfeldt, forthcoming in August 2017). 
